Fiscal Sustainability: Does EU Membership Change Policy Behavior? Empirical Evidence from Central and Eastern Europe

\author{
Bettina Fincke
}




\title{
Fiscal Sustainability: Does EU Membership Change Policy Behavior? Empirical Evidence from Central and Eastern Europe
}

\author{
Bettina Fincke*
}

\begin{abstract}
This paper studies fiscal policy behavior with regard to sustainability for the group of the eight eastern new member states (NMS) which joined the European Union (EU) in 2004. Using the approach of Bohn $(1995,1998)$ the fiscal reaction function is estimated for the years 1995 until 2013. Further, by separating the response in periods before and after accession, it is possible to study potential changes in fiscal sustainability. The results of the panel regressions reveal a positive statistically significant reaction coefficient, indicating sustainable behavior. Moreover, the separated responses before and after 2004 signify a stronger reaction ahead of the accession. Plus, effects of the crisis should be taken into account.
\end{abstract}

JEL: H63, E62

Keywords: Fiscal Sustainability, Public Finances, New EU Member States

This paper is part of the research project "Bright Prospects? 10 Years after the EU's first eastward enlargement; Economic Growth in transition economies in Central and Eastern Europe in the context of public debt sustainability". Financial support from the Bielefelder Nachwuchsfond is gratefully acknowledged. I thank colleagues for their valuable comments.

*Department of Business Administration and Economics, Bielefeld University, P.O. Box 100131, 33501 Bielefeld, Germany. Phone: (+49) 521106 4858, E-mail: bfincke@wiwi.uni-bielefeld.de 


\section{Introduction}

With the recent crisis, aspects of fiscal sustainability evoke as the public budget situation impaired, fiscal deficits increased and the debt situation regained particular interest. This development was accompanied by a severe recession. Due to that, regular budget sourcing through tax revenues aggravated and sustainability of public finances was challenged. Many economies worldwide were hit by the financial and debt crisis, however, Europe was affected especially strong. This situation was not limited to Western European economies like Greece, Ireland, Portugal or Spain, who had to apply for financial assistance. Central and Eastern European Union members, like Slovenia for instance, and potential future new member states in Eastern Europe were affected, too, and suffered from serious difficulties. As mentioned by Staehr (2010) for instance Latvia and Hungary suffered from severe problems leading to bailouts.

In this context it is important to recall that for EU members the Maastricht Treaty and the Stability and Growth Pact require sound fiscal positions, as it is recorded in Art. 121 of the treaty. These requirements intensify the sustainability considerations for all member states. Relating to that it is interesting to consider the EU's first eastward enlargement of 2004. On May $1^{s t} 2004$ the ten countries Cyprus, Czech Republic, Estonia, Hungary, Latvia, Lithuania, Malta, Poland, Slovakia and Slovenia were joining the union and all of them had to fulfill the obligations to become member states. However, in view of the current economic situation in Europe some question in this context arise for the new member states $(\mathrm{NMS})^{1}$ as regards fiscal sustainability. Therefore, this study contributes to research on sustainability in NMS by analyzing whether the governments of the NMS pursue sustainable fiscal policies and whether EU membership has changed fiscal policy behavior. This becomes especially relevant since 2014 is the 10 year commemoration of the EU's eastward enlargement. These are the central research questions for this study, which will be analyzed empirically using the fiscal response approach of Bohn $(1995,1998)$. The idea is to test whether a government reacts in a counter-acting manner with its primary balance to changes in its debt situation. In a second step, the accession in 2004 is taken into account by analyzing if this policy behavior changed before and after joining the EU. The study is conducted with annual data for the period from 1995 to 2013. This allows

$\overline{1}$ This study concentrates on the eastern NMS, thus, in line with Stanek (2014), Cyprus and Malta are not considered here. 
to cover some years of the transition phase as well as the recent troubles with the crisis. The remainder of this paper is organized as follows: section 2 presents a literature overview covering both, empirical studies on sustainability in general and those with special focus on Central and Eastern European countries (CEEC), section 3 presents the data set and the estimations and their results. Section 4 summarizes and concludes.

\section{Literature overview}

Several papers in the economics literature address fiscal sustainability aspects, mainly based on the concept of the inter-temporal budget constraint. Here, the focus is set on empirical contributions. As Chalk and Hemming (2000) pointed out, there is basically two lines of sustainability research, indicators and time series approaches. The former presents sustainability information in one figure, as for instance suggested by Blanchard et al. (1990) or Blanchard (1990). However, this ease also comes along with several drawbacks. $^{2}$ The other type started with a seminal paper by Hamilton and Flavin (1986), who utilize stationarity tests to assess traits of the present value budget constraint. Within this branch, mainly three approaches of testing for fiscal sustainability emerged. Trehan and Walsh (1991) suggest to test for the stationarity properties of the budget deficit in order to test for fiscal sustainability. Sustainability is inferred for stationary deficits, assuming that the variable real interest rate is positive. Hakkio and Rush (1991) propose a co-integration test. Sustainability is reasoned for if public revenues and expenditures are co-integrated. Bohn $(1995,1998)$ introduces fiscal response functions. If the primary surplus ratio reacts in an enhancing manner to increases of the public debt ratio, fiscal sustainability seems to be given. For an overview and discussion of fiscal sustainability approaches see e.g. Afonso (2005) or Chalk and Hemming (2000).

Many applications have followed. To mention just a few (arbitrarily) selected ones: for instance, Sawada (1994) studies sustainability for some Latin American and Asian countries according to the first two approaches mentioned above, i.e. Trehan and Walsh (1991) and Hakkio and Rush (1991). Whereas, for example, Burger (2012) and Fincke and Greiner (2011a) utilize Bohn $(1995,1998)$ 's approach in order to calculate stabilized debt ratio values for the US and UK or detect changes in the response over time for certain EU

$2 \quad$ For a more detailed discussion on these literature approaches see for example Fincke (2012). 
(crisis) economies, respectively.

However, concerning specifically Eastern European countries the amount of contributions becomes more sparsely. Many early papers focus on the role of fiscal policy in the transition process, i.e. the phase of shift from planned to market economies. In a recent paper, Shabunina (2013) portrays the (chronological) development of the fiscal policy situation in transition economies, starting with the early phase in the 1990s until the recent period with the crisis. She takes heterogeneity of the countries into account by distinguishing different groups (per phase) and illustrates the discussion by data and statistics on budget variables. Her overview shows that there has been some improvement in fiscal policy in CEECs, however, challenges remain. Further, for instance Darvas (2009) reflects the role of the current crisis on fiscal policy in CEECs. Using statistics and structural vectorautoregressions he stresses the influence of high private debt, dependence on international relations (trade and capital flow) and pro-cyclicality of fiscal policy. Accordingly, the crisis should be taken as a chance for reforms and improvement.

As concerns sustainability studies, there are some that focus on indicators, Budina and Van Wijnbergen (1997) for instance. Adapted from the government's inter-temporal budget constraint, they calculate sustainable primary balances which aim at stabilizing the debt to GDP ratio. With these indicators they distinguish three groups: sustainable economies, borderline cases and unsustainable countries. They find that sustainable countries have lower inflation and they grow earlier and faster. Later, Aristovnik and Bercic (2007) also study fiscal sustainability by calculating indicators for the (required) fiscal balance and public debt ratios. They take annual data for 24 transition economies and distinguish three groups: Central and Eastern Europe, Southern and Eastern Europe and Commonwealth of Independent States. Their results indicate that some countries don't pursue sustainable policies, in particular they mention Czech Republic, Hungary, Poland, Albania and Croatia.

Going beyond indicators, other contributions employ time series analysis. For instance, Stanek (2014) analyses debt sustainability in the NMS by conducting panel data stationarity tests on the debt to GDP ratio for quarterly data from 2000 to 2013. He studies whether Euro-zone members of the group behave different than the others, where he also runs subsamples with/without the crisis years. His results yield that Euro-zone members do not perform better than the other CEECs concerning debt sustainability. Llorca and 
Redzepagic (2008), for example, test for sustainability with the co-integration approach. They analyze the government spending and revenue development with a panel of quarterly data for eight selected new EU member states; their results indicate sustainability. And, Stoian and Câmpeanu (2010) analyze fiscal sustainability in CEECs by applying Bohn's fiscal response approach for instance. They estimate regression equations individually for all ten economies with OLS based on quarterly data for 2000 until 2008. The results are mixed, they indicate sustainable behavior for some countries (Bulgaria, Czech Republic, Estonia and Lithuania), whereas others (Latvia, Poland, Romania and Slovenia) face difficulties. Also, Staehr (2010) and Baldi and Staehr (2013) utilize fiscal response functions to study the public finance situation in CEECs with a special focus on the current crisis. Baldi and Staehr (2013) analyze fiscal reaction functions before and after the current crisis - and possible changes - in order to explain the different fiscal performance situation of EU economies. They utilize panel regressions for different groups of EU members, diversified by characteristics of integration (in this way including CEECs) and crisis impact, with quarterly data from 2000-2012 in separated two-part (pre-crisis and post-crisis) estimations. They find a change in policy: with only a slight and rather similar response before the crisis, but a stronger debt effect after 2008, especially for crisis-affected economies. By applying Bohn's approach, this paper goes into a similar direction like Stoian and Câmpeanu (2010) and Baldi and Staehr (2013), however, a special focus is set on the 2004 enlargement, meaning, this contribution not only tests sustainability for the eastern NMS in general, but especially accounts for the behavior before and after EU accession. Moreover, the data set runs from 1995 until 2013 with annual data, allowing to include the early stage as well as the recent crisis.

\section{Empirics}

This section presents the empirical estimations and results. Ahead of that, some information on the data set is present to get a first impression of the public finance situation in the eight countries under consideration. 


\subsection{Dataset}

The data set covers annual data for the years from 1995 until 2013 for the eight eastern NMS that joined in 2004: Estonia, Latvia, Czech Republic, Lithuania, Hungary, Poland, Slovenia and Slovak Republic. ${ }^{3}$ In order to test for sustainable behavior in the NMS with Bohn $(1995,1998)$ 's fiscal response approach, the focus is set on the two central variables primary balance to GDP ratio and public debt to GDP ratio. To get a first visual impression, figures 1 and 2 depict their development.

The primary balance reveals a rather wiggly behavior with most movement in terms
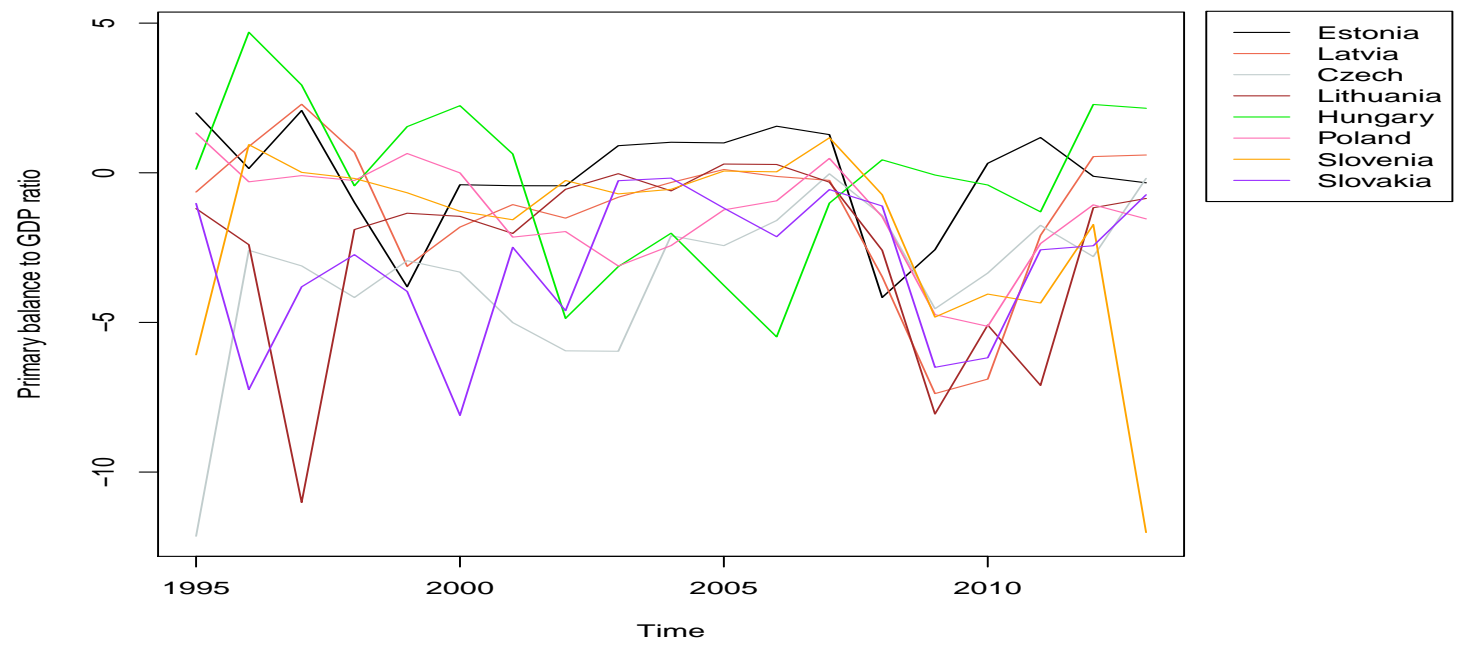

Figure 1: Primary balance NMS (1995-2013)

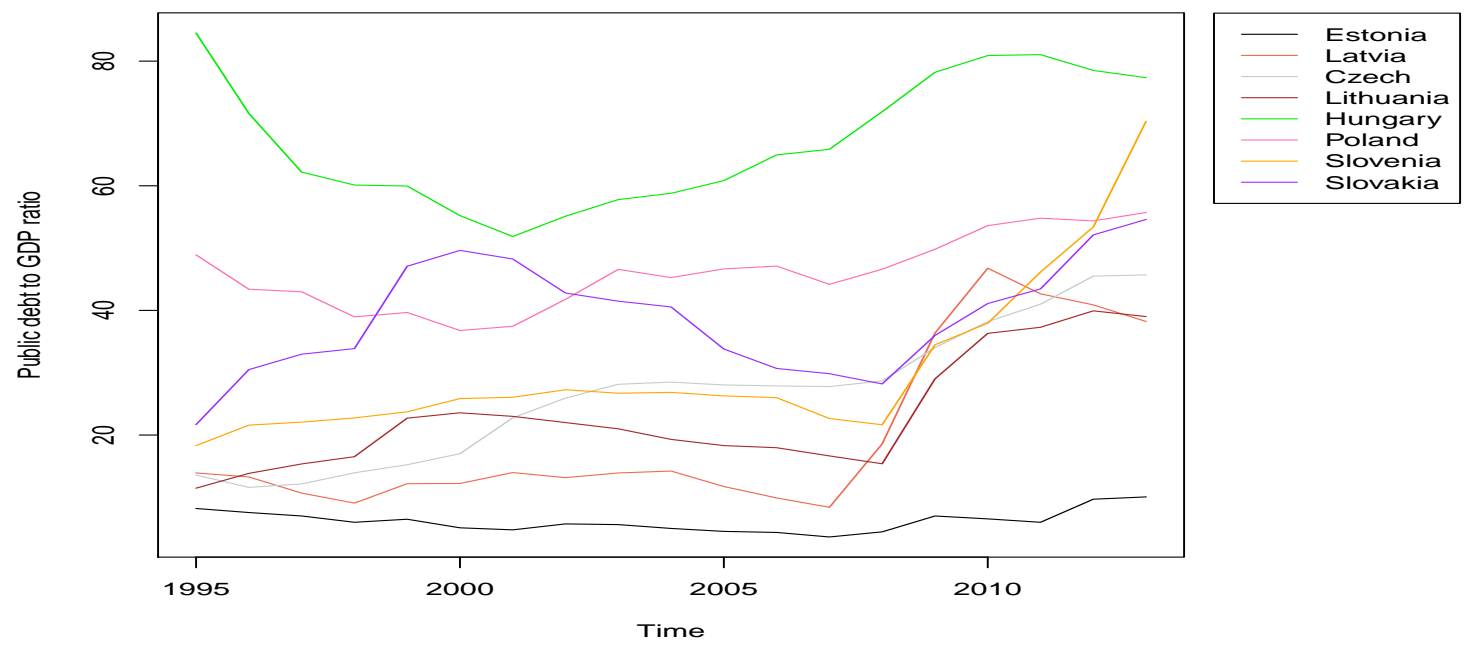

Figure 2: Public debt ratio NMS (1995-2013)

3 Again, the focus is set on the eastern NMS, thus, Cyprus and Malta are not considered here. 
of (smaller) deficits. Summarizing the primary balance ratio across time and countries yields a value of $-1.72 \%$, indicating that on average the NMS run primary deficits over this time horizon. As regards the public debt ratio the initial situation in the Baltic states for instance was characterized by very low values, whereas Hungary revealed a value of $84.5 \%$, which decreased until the early 2000s. Also, the strong increase of the Slovenian public debt ratio is noteworthy, which almost quadrupled from $18 \%$ in 1995 to $70 \%$ in 2013. Certainly, the recent crisis is visible in the most current observations.

For the estimations the data set is used as a panel, meaning the NMS are treated as a group unlike other country-by-country studies such as Stoian and Câmpeanu (2010) for instance. The reason for this is to analyze the common behavior across all NMS (due to the accession), rather than individual country actions. Plus, for such a procedure the series are likely to be too short. In order to incorporate the different behavior before and after the accession, the data series are separated after 2003. Since the data set refers to annual data and the NMS joined on May 1st 2004, most of that year they were EU members, thus, it is reckoned for the second part

Due to availability the data set has been constructed using different (but few) sources. GDP and the deflator stem from International Monetary Fund (2014). The primary balance and public debt ratio mainly come from European Central Bank (2015), seldomly missing observations have been supplemented (after careful examination of trend and neighbors) by OECD (2014) entries (Estonian and Czech public debt and primary balance data, however, mainly stems from the latter source. $)^{4}$. Total public spending has mainly been extracted from AMECO (2015), rarely missing data has been supplemented by International Monetary Fund (2014) observations. Appendix A provides a more detailed data set description.

Due to utilization of lagged debt ratio variable in the regressions, the series for all variables in the estimations cover the years from 1996-2013, except for the debt ratio, which runs from 1995 to 2012. For both figures, from a first rough descriptive and graphical impression, no particular impact of the 2004 enlargement is directly visible. Therefore, in a next step, the response function according to Bohn $(1995,1998)$ will be estimated in order to analyze the fiscal sustainability behavior further.

$4 \quad$ For Latvia the primary balance ratio data for 2010-2012 have been calculated manually by resorting to Central Statistical Bureau of Latvia (2015) and World Bank (2015), see appendix A for details. 


\subsection{Estimation results}

For a more profound analysis, the following regression for a simple OLS Panel model will be estimated:

$$
p s_{i, t}=\alpha_{0}+\gamma b_{i, t-1}+\sum_{j} \alpha_{j} Z_{j, i, t}+\epsilon_{i, t}
$$

where $p s_{i, t}$ indicates the primary balance to GDP ratio for country $i$ at time $t$. The variable $b$ represents the public debt to GDP ratio and $\epsilon$ is the error term. The vector of the control variables is denoted by $Z_{j, i, t}$. These additional aspects are twofold: they contain a variable, which is motivated by the tax smoothing hypothesis, stating that a government shall run public deficits in order to keep the tax rates constant. So, a term is included to account for fluctuations: a business cycle variable, YGap, which is constructed like an output gap ratio, i.e. $\frac{\left(Y_{t}-Y^{*}\right)}{Y^{*}}$, with $Y$ for the real GDP and $Y^{*}$ its trend constructed with a moving average. ${ }^{5}$ Moreover, the inflation rate $I n f l$ is included, as it accounts for changes in the price level and captures some influence from monetary policy. The debt ratio is included in lagged terms. On the one hand, economically, this allows to capture the actual response on realized (past) values of the debt ratio. On the other hand, technically, this mitigates endogeneity.

Since the focus is set on whether the 2004 enlargement did change this fiscal behavior in the context of sustainability for the eight eastern NMS, in a next step the main effect and the response parameter $\gamma$ will be dismantled in order to account for different behavior before and after accession separately. Thus, two interaction terms are introduced, which capture the fiscal response in the two periods $(B A=$ before accession, i.e. (1996-2003) and $A A=$ after accession, i.e. (2004-2013)), respectively. They are constructed with a Dummy $D$ containing ones and zeros: ${ }^{6}$

$$
p s_{i, t}=\phi_{0}+\gamma_{B A} b_{i, t-1} * D_{B A}+\gamma_{A A} b_{i, t-1} * D_{A A}+\sum_{j} \phi_{j} Z_{j, i, t}+\epsilon_{i, t}
$$

For both equations three model types are estimated: a simple pooled model, a fixed effects model and a random effects model. Table 1 summarizes the information on the reaction coefficients. $^{7}$

\footnotetext{
$5 \quad$ For a similar approach, using the HP-Filter, see for instance Fincke and Greiner (2011b).

6 For instance $D_{B A}$ contains ones for the years 1996 until 2003 and zeros afterwards.

7 Full estimation outcomes are reported in appendix A. All estimation are implemented with package $p l m$ in R 3.1.2.
} 


\begin{tabular}{|c|ccc|}
\hline Common effect & pooled & fixed effects & random effects \\
\hline \hline$\gamma$ & $0.018^{\bullet}$ & $0.050^{*}$ & $0.026^{\bullet}$ \\
\hline \hline F Test & $F=3.739$ & p-val. $=0.000995$ & \\
Hausman Test & $\chi^{2}=44.142$ & p-val. $=1.41 \cdot 10^{-9}$ & \\
\hline
\end{tabular}

\begin{tabular}{|c|ccc|}
\hline Separated effects & pooled & fixed effects & random effects \\
\hline \hline$\gamma_{B A}$ & 0.013 & $0.060^{*}$ & 0.025 \\
$\gamma_{A A}$ & $0.020^{\bullet}$ & $0.052^{*}$ & 0.026 \\
\hline \hline F Test & $F=3.726$ & $\mathrm{p}-\mathrm{val} .=0.00103$ & \\
Hausman Test & $\chi^{2}=31.845$ & $\mathrm{p}-\mathrm{val} .=2.06 \cdot 10^{-6}$ & \\
\hline \hline Signf. levels & $* *(1 \%$ level $)$ & $*(5 \%$ level $)$ & $\bullet(10 \%$ level $)$ \\
\hline
\end{tabular}

Table 1: Estimation results for the reaction coefficient.

The first part of table 1 presents the outcomes of the estimation of equation (1) for all model types. $\gamma$ presents the common response parameter for the eastern NMS, indicating whether their governments reacted to changes in their public debt ratio by adjusting their primary balance ratios. A positive coefficient signifies sustainable behavior as, for instance, an increase in the debt ratio goes along with enhancing the primary surplus (or reducing deficits). The results reveal a positive and significant coefficient, indicating sustainable fiscal behavior for the group of the eastern NMS for the years from 1996 to 2013. Some tests for the more appropriate model type are conducted: the F test compares the pooled model and the fixed effects model, small p-values suggest to choose the fixed effects model. The Hausman test compares the fixed effects model with the random effects model, again a small p-value suggest the fixed effects model. The tests indicate that the fixed effects model seems to be most suitable here. However, the central result of sustainability is affirmed for all three specifications (model types).

Moreover, the second part of table 1 present the estimation outcomes of the segregated fiscal reactions. The coefficients $\gamma_{B A}$ and $\gamma_{A A}$ both possess a positive sign for all estimation types. Interestingly, for the pooled and the random effects model, only the coefficients for the period after 2004 are statistically significant, whereas in the fixed effects model both are significant. However, the tests indicate that the fixed effects model is the better choice. Referring to that fixed effects model, the estimation of the separated fiscal reac- 
tion reveals additional information: by splitting the response into periods before and after accession, the reaction seems to be stronger in the years before 2004. This holds true for both, the magnitude of the coefficient as well as the significance level. Economically this makes clear sense, as the countries were putting strong effort and emphasis on fulling the criteria for the membership.

In order to test further on the estimations, some robustness checks were conducted. For instance, the estimations are run with a truncated sample, cutting the data set after 2008 leaving out all crisis observations. The results confirm the outcomes presented in table $1 .^{8}$ Again, the fixed effects model seems to present the best choice, for which the reaction coefficients are significantly positive. Plus, for the separated responses, the reaction was stronger before accession. If the regressions are implemented in manner of Baldi and Staehr (2013), that is cutting or splitting the whole data set in between 2003 and 2004, and running the estimations with two (unrestricted) models before accession (1996-2003) and after accession (2004-2013) (compared to the restricted, full time span model as discussed above), yields some interesting additional insights. For the pre-EUphase the positive debt reaction presents the only significant effect in the model, whereas in the post-accession model the business cycle variable becomes the only significant influence (positive sign). This supports the findings from above by stressing the debt response effect ahead of the entry, which can be interpreted as the enhanced efforts, and also indicating potential crisis influences afterwards. Moreover, if the second period of the unrestricted model is run until 2008 only (i.e. 2004-2008), this splitted model allows to account for potential crisis effects. It yields for the second phase not only a significant YGap coefficient but also a significant (strong) positive response parameter. Obviously, as regards debt sustainability, there is a crucial influence of the crisis, which should not be neglected. ${ }^{9}$ Moreover, if the fluctuation is measured by a different variable, that is in terms of deviations of total public expenditure from its trend, GGap, which is constructed similar to YGap, the positive sign of the reaction coefficient remains, however, there is a loss of significance.

\footnotetext{
$8 \quad$ Only the pooled model looses significance for the reaction coefficient (but it misses the $10 \%$ reference value only closely for the common response.)

$9 \quad$ Here, even for running a simple model (without controls, i.e. the lagged debt ratio variable is the single explanatory variable) it's also crucial to take the crisis effect into account as the response only becomes significant for the truncated sample (cutting after 2008).
} 
Summing up, there are some indications for fiscal sustainability in the eight eastern NMS for the considered time period. Relating this result to other literature contribution is kind of tricky, as for instance Stoian and Câmpeanu (2010), Aristovnik and Bercic (2007), Baldi and Staehr (2013) or Stanek (2014) work with a different testing framework: the first two contributions perform country-by-country studies yielding mixed results for sustainable behavior and Baldi and Staehr (2013) and Stanek (2014) have put the focus on a comparison of pre-crisis and post-crisis behavior or Euro-zone to Non-Euro-zone members, respectively. Nevertheless, the results presented in table 1 offer some new and current empirical research regarding sustainability studies for Eastern European Union members with special emphasis on the 2004 accession. Certainly, further research this direction in the future is necessary in order to study the fiscal behavior of EU applicant countries or future EU members.

\section{Summary}

This paper studies the fiscal policy behavior for the group of the eight eastern new member states which joined the European Union in 2004. The approach of Bohn $(1995,1998)$ is used to estimate the fiscal reaction function with annual data for the years 1995 until 2013 with panel regressions. By separating the response in periods before and after accession, it is possible to study potential changes in fiscal sustainability behavior. The results of the estimations reveal a positive statistically significant reaction coefficient indicating sustainable behavior. This results is shown for all three model types, i.e. pooled OLS, fixed effects and random effects. The fixed effects type presents the most suitable model. In a second step, the responses are estimated separately in order to capture the behavior before and after 2004. Again, the fixed effects estimation presents the best model choice. The outcome signifies a stronger reaction ahead of the accession, this is reasonable from an economic point of view, as it covers the preparation phase before joining the EU and shows the effort of fulfilling the qualification criteria. Moreover, the estimations indicate considerable influence of the current crisis on the sustainability situation, which should be kept in mind for the interpretation. Certainly, these results only hold true for the considered time period. In order to maintain the sustainable fiscal situation, the governments of the economies need to continue pursuing their counter-acting behavior and adhere to that policy. 


\section{References}

Afonso, A. (2005). Fiscal sustainability: the unpleasant European case. Finanzarchiv 61 (1), 19-44.

AMECO (2015). Annual macro-economic database of the European Commission's Directorate General for Economic and Financial Affairs (DG ECFIN), Ameco online, http: //ec.europa.eu/economy_finance/ameco/user/serie/SelectSerie.cfm, last access: February 23rd, 2015.

Aristovnik, A. and B. Bercic (2007). Fiscal sustainability in selected transition countries. MPRA Paper No. 122, http://mpra.ub.uni--muenchen.de/122/1/MPRA_ paper_122.pdf, last access: February 24th, 2015.

Baldi, G. and K. Staehr (2013). The European Debt Crisis and Fiscal Reaction Functions in Europe 2000-2012. DIW Discussion Paper No. 1295, http://ssrn.com/abstract= 2268992, last access: March 18th, 2015.

Blanchard, O., J.-C. Chouraqui, R. P. Hagemann, and N. Sartor (1990). The Sustainability of fiscal policy: new answers to an old question. OECD Economic Studies 15 (Autumn), 7-36.

Blanchard, O. J. (1990). Suggestions for a New Set of Fiscal Indicators. OECD Economics Department Working Papers No. 79, OECD Publishing.

Bohn, H. (1995). The sustainability of budget deficits in a stochastic economy. Journal of Money, Credit and Banking 27 (1), 257-271.

Bohn, H. (1998). The behavior of U.S. public debt and deficits. The Quarterly Journal of Economics 113 (3), 949-963.

Budina, N. and S. Van Wijnbergen (1997). Fiscal policies in eastern europe. Oxford Review of Economic Policy 13(2), 47-64.

Burger, P. (2012). Fiscal Sustainability And Fiscal Reaction Functions In The US And UK. International Business \& Economics Research Journal 11 (8), 935-942. 
Central Statistical Bureau of Latvia (2015). Statistics Database, Government Finances, http://www.csb.gov.lv/en/dati/statistics-database-30501.html, last access: February 9th, 2015.

Chalk, N. and R. Hemming (2000). Assessing Fiscal Sustainability in Theory and Practice. IMF Working Paper WP/00/81, i-27, International Monetary Fund, Washington D.C.

Darvas, Z. (2009). The impact of the crisis on budget policy in central and eastern europe. Bruegel Working Paper No. 2009/05.

European Central Bank (2015). Statistical Data Warehouse, http://sdw.ecb.europa. eu/, last access: February 19th, 2015.

Fincke, B. (2012). Public Debt Sustainability: From Roots to Regressions. PhD Thesis (Dissertationsschrift), Universität Bielefeld, Fakultät für Wirtschaftswissenschaften, Bielefeld, Germany, http://pub.uni-bielefeld.de/publication/2564789, last access: February 10th, 2015.

Fincke, B. and A. Greiner (2011a). Debt sustainability in selected euro area countries. Empirical evidence estimating time-varying parameters. Studies in Nonlinear Dynamics E) Econometrics 15 (3), Article 2.

Fincke, B. and A. Greiner (2011b). Do large industrialized economies pursue sustainable debt policies? A comparative study for Japan, Germany and the United States. Japan and the World Economy 23 (3), 202-213.

Hakkio, C. S. and M. Rush (1991). Is the budget deficit "too large?". Economic Inquiry 29 (3), 429-445.

Hamilton, J. D. and M. A. Flavin (1986). On the Limitations of Government Borrowing: A Framework for Empirical Testing. The American Economic Review 76 (4), 808-819.

International Monetary Fund (2014). World Economic Outlook database, October 2014, http://www.imf.org/external/pubs/ft/weo/2014/02/weodata/index.aspx, last access: February 23rd, 2015.

Llorca, M. and S. Redzepagic (2008). Debt sustainability in the EU New Member States: empirical evidence from a panel of eight Central and East European countries. PostCommunist Economies 20(2), 159-172. 
OECD (2014). OECD Economic Outlook No. 96, OECD Economic Outlook: Statistics and Projections (database), http://www.oecd-ilibrary.org/economics/ data/oecd-economic-outlook-statistics-and-projections_eo-data-en, last access: February 19th, 2015.

Sawada, Y. (1994). Are the heavily indebted countries solvent?: Test of intertemporal borrowing constraints. Journal of Development Economics 45, 325-337.

Shabunina, A. (2013). Fiscal policy in transition economies - sustainable public finance as a measure of successful transition. In P. Hare and G. Turley (Eds.), Handbook of the economics and political economy of transition, pp. 148-163. Routledge.

Staehr, K. (2010). The Global Financial Crisis and Public Finances in the New EU Countries in Central and Eastern Europe: Developments and Challenges. Public Finances and Management 10 (4), 671-712.

Stanek, P. (2014). Public debt sustainability and the participation of the new member states in the euro area. Poznan University of Economics Review 14(4), 22-37.

Stoian, A. and E. Câmpeanu (2010). Fiscal policy reaction in the short term for assessing fiscal sustainability in the long run in central and eastern european countries. Czech Journal of Economics and Finance (Finance a uver) 60 (6), 501-518.

Trehan, B. and C. E. Walsh (1991). Testing Intertemporal Budget Constraints: Theory and Applications to U.S. Federal Budget and Current Account Deficits. Journal of Money, Credit and Banking 23 (2), 206-223.

World Bank (2015). World Development Indicators, Last Updated: 01/30/2015, last access: February 23rd 2015.

\section{A Additional data information and estimation results}

This section provides additional information on the data set, which has been constructed by resorting to different but few sources. Table 2 summarizes the central information. Please note, for Latvia the observations for the primary balance ratio 2010-2012 have been calculated manually by resorting to Central Statistical Bureau of Latvia (2015) and 


\begin{tabular}{|c|c|c|c|c|c|}
\hline \multirow[t]{2}{*}{ Variable } & \multirow[t]{2}{*}{ Source } & \multirow[t]{2}{*}{ No. of obs. } & \multicolumn{3}{|c|}{ Descriptive Statistics } \\
\hline & & & Mean Min. & Max. & St.D. \\
\hline Primary balance & $\begin{array}{c}\text { ECB (2015) } \\
\text { OECD (2014) }\end{array}$ & 144 & $-1.72-4.84$ & 0.09 & 1.16 \\
\hline Public debt & $\begin{array}{c}\text { ECB (2015) } \\
\text { OECD (2014) }\end{array}$ & 144 & $31.40 \quad 25.16$ & 46.80 & 6.64 \\
\hline YGap & $\begin{array}{l}\text { GDP: IMF (2014) } \\
\text { Defl.: IMF (2014) }\end{array}$ & 144 & $3.10-5.40$ & 6.19 & 2.78 \\
\hline Infl & Defl.: IMF (2014) & 144 & 4.820 .56 & 14.17 & 3.29 \\
\hline GGap & $\begin{aligned} & \text { Exp.: } \text { AMECO (2015) } \\
& \operatorname{IMF}(2014) \\
& \text { Defl.: IMF }(2014)\end{aligned}$ & 144 & $\begin{array}{ll}1.56 & -1.80\end{array}$ & 3.61 & 1.46 \\
\hline
\end{tabular}

Table 2: Detailed data information (own calculations).

World Bank (2015), meaning the primary spending has been calculated by correcting total expenditures by interest payments. Further, Lithuania's public debt ratio data for 2000-2003 stem from International Monetary Fund (2014).

The descriptive statistics refer to the averages cross countries of the actually used data in the regressions, meaning for the eight eastern NMS with data from 1996-2013, except for the lagged debt ratio (1995-2012). The (local) trend for calculating YGap and GGap has been computed with moving averages: 3-periods for YGap (except for Lithuania and Czech, for which only 2-period steps were possible) and 2-periods for GGap. Plus, they are computed backward-looking in order to use available observations. The statistics reveal, that for the group of the eight NMS the primary balance ratio was in deficit on average, with the maximum group primary deficit of almost 5\% in 2009 and the largest group value of nearly $1 \%$ in 2007 . The average value for the debt ratio in the NMS is $31.4 \%$ with the lowest value of about $25 \%$ in 1999 and the highest value of $46.8 \%$ in 
2013 with the crisis. The average output gap ratio for the considered period is $3.1 \%$, with the minimum in 2009 and the highest value in 2007. The average inflation in the group was about 5\%, with the lowest value in 2010 and the maximum of $14.17 \%$ in 1996 . On average, government spending was above the trend, interestingly, the maximum of $3.6 \%$ was run in 2008, whereas minimum of almost $2 \%$ was run in 2010 . The latter number indicating that in that year, public expenditures were below its trend (measured as ratio to trend), which could be assigned to enforced consolidation/ austerity measures. Whenever necessary adjustment to Euro has been calculated according to the official rate, for instance for some Lithuanian data with $3.45280 \mathrm{LTL}=1 €$.

As regards the stationarity properties of the series utilized in the regression, ahead of the estimations Augmented Dickey-Fuller Test have been conducted. They reveal stationarity for all variables except the debt ratio. However, with $p-$ value $=0.1691$ it comes rather close. Further, Burger (2012, pp. 937f.) discusses this issue and points out that Bohn didn't particularly check stationarity of the series. Here, stationarity (or relatively close proximity) is assumed.

The full estimation results for equations (1) and (2) are given as follows:

1) For the general and common response:

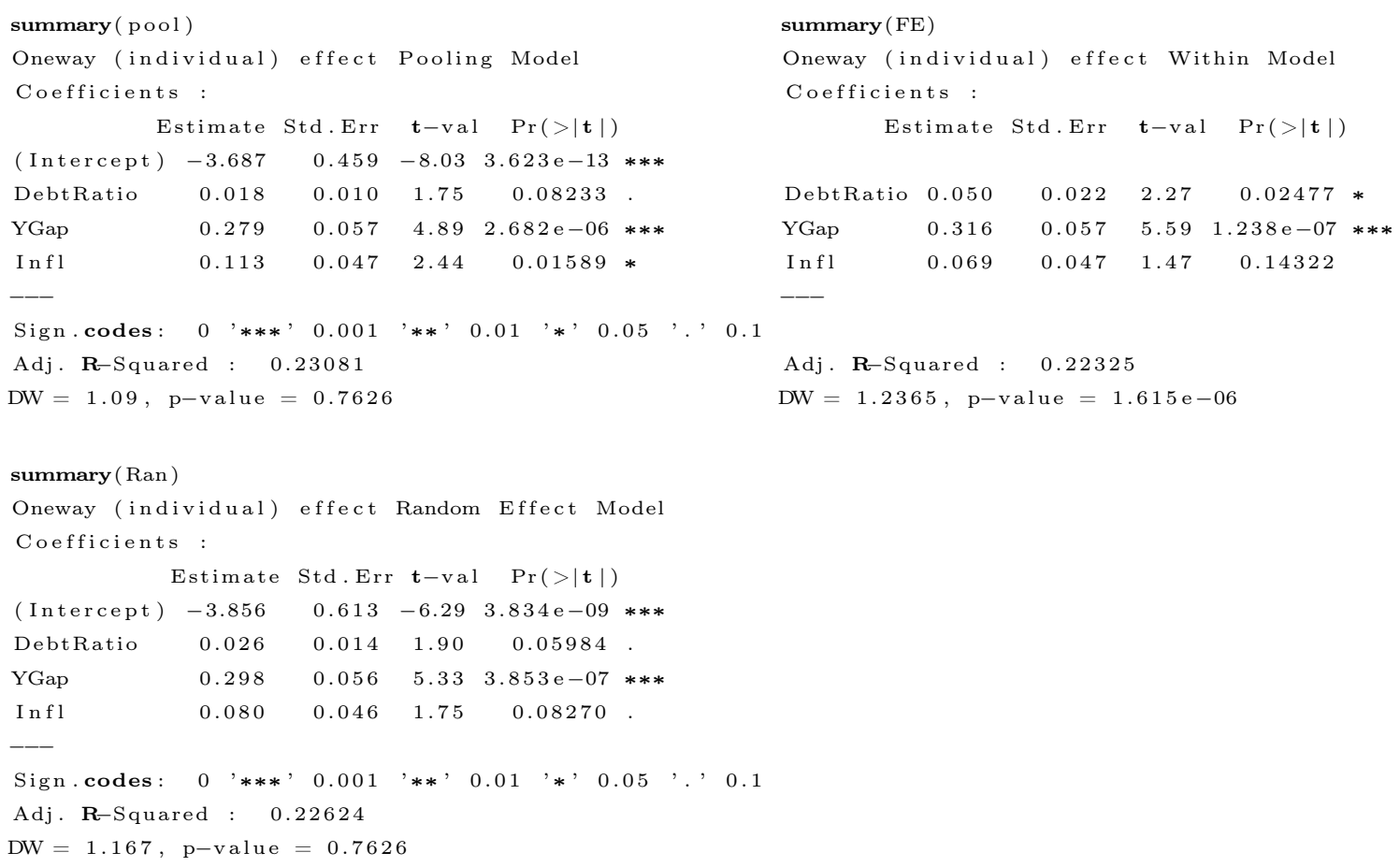


2) For the separated responses before and after 2004:

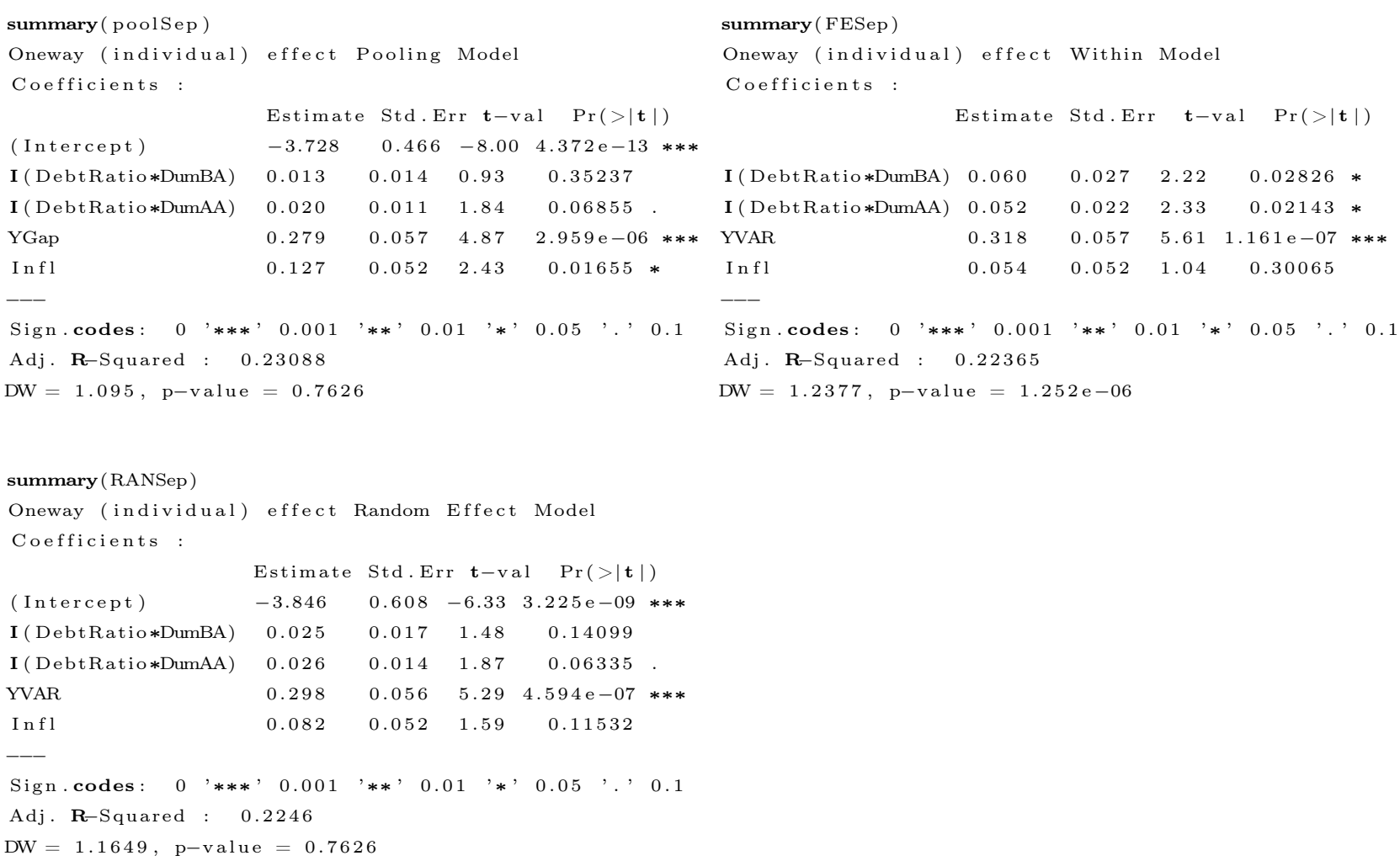

